logical $\mathrm{pH}$, which obviously would be required for the performance of a cytoskeletal function.

1. Eriksson, A. and Thornell, L.-E. J. Cell Biol. 80 (1979) 231.

2. Stigbrand, T., Eriksson, A. and Thornell, L.-E. Biochim. Biophys. Acta 577 (1979) 52.

Received May 29, 1979.

\section{Partial Reaction of Thymine}

7-Hydroxylase*

\section{ELISABETH HOLME, GÖRAN LINDSTEDT and SVEN LINDSTEDT}

Department of Clinical Chemistry, University of Gothenburg, Sahlgren's Hospital,

S-413 45 Gothenburg, Sweden

Thymine 7-hydroxylase (EC 1.14.11.6) from Neurospora crassa catalyzes the sequential oxygenation of thymine to 5-carboxyuracil via 5-hydroxymethyluracil and 5-formyluracil. In each step 2-oxoglutarate is oxidatively decarboxylated to carbon dioxide and succinate. ${ }^{1}$ A reaction mechanism has been proposed in which 2-oxoglutarate reacts with oxygen to produce monopersuccinic acid as the reactive intermediate which acts as hydroxylating agent on the other substrate. ${ }^{2}$ This mechanism is supported by reports on uncoupling of the 2 oxoglutarate decarboxylating activity from hydroxylation in reactions catalyzed by thymine 7-hydroxylase ${ }^{3}$ and proline hydroxylase. ${ }^{4,5}$ In preparations of thymine 7-hydroxylase, we have observed a 2-oxoglutarate decarboxylating activity, which depends on pyrimidines that are noncompetitive inhibitors of the thymine hydroxylase activity. ${ }^{6}$

In the presence of these inhibitors the formation of ${ }^{14} \mathrm{CO}_{2}$ from 2-oxo $\left[1-{ }^{14} \mathrm{C}\right]$ glutarate is linear with enzyme concentration and linear with time for $10 \mathrm{~min}$. The pyrimidines which are active in promoting the reaction are listed in Table 1. The same cofactors are required as for the thymine hydroxylase activity (Table 2) but there is an absolute requirement for ascorbate. Possibly, ascorbate protects the enzyme from

* Communication at the Meeting of the Swedish Biochemical Society in Gothenburg, 7-8th June, 1979.

Table 1. 2-Oxoglutarate decarboxylating activity in the presence of various pyrimidines. For incubating conditions and specific activity of enzyme in the complete systems see Experimental.

\begin{tabular}{lcc}
\hline $\begin{array}{l}\text { Pyrimidine } \\
\text { added }\end{array}$ & $\begin{array}{l}\text { Specific } \\
\text { activity } \\
\mu \text { mol min }\end{array}$ & $\begin{array}{l}\text { Relative } \\
\text { activity } \\
\%\end{array}$ \\
\hline Thymine & 74 & 100 \\
5-Aminouracil & 4.9 & 6 \\
5-Hydroxyuracil & 2.3 & 3 \\
5-Mercaptouracil & 2.1 & 3 \\
Uracil & 0.7 & 1 \\
None & 0.1 & 0.1 \\
\hline
\end{tabular}


Table 2. Formation of ${ }^{14} \mathrm{CO}_{2}$ from 2 -oxo $\left[1 .{ }^{14} \mathrm{C}\right]$ glutarate relative to that in the complete system with thymine and 5-aminouracil. For incubating conditions and specific activity of enzyme in the complete systems see Experimental.

\begin{tabular}{|c|c|c|}
\hline \multirow{2}{*}{$\begin{array}{l}\text { Compound } \\
\text { omitted }\end{array}$} & \multicolumn{2}{|c|}{$\%$ Activity } \\
\hline & Thymine & 5-Aminouracil \\
\hline None & 100 & 100 \\
\hline Pyrimidine & 0 & 0 \\
\hline Ascorbate & 22 & 0 \\
\hline $\mathrm{Fe}^{2+}$ & 1 & 2 \\
\hline Catalase & 20 & 52 \\
\hline
\end{tabular}

inactivation by a reactive intermediate formed in the oxidative decarboxylation of 2oxoglutarate. When the enzyme was stored at $-20^{\circ} \mathrm{C}$ the thymine hydroxylating activity decreased more rapidly than the activity catalyzing decarboxylation of 2-oxoglutarate in the presence of pyrimidine inhibitors. When the protein was heated at $42^{\circ} \mathrm{C}$ in $10 \mathrm{mM}$ potassium phosphate buffer (pH 6.5) containing $\mathrm{KCl}$ (50 mM), EDTA (0.1 mM) and glycine (100 mM) the half lives for decrease of the two activities was about the same ( $13 \mathrm{~min})$. The two activities could not be separated in a purification procedure where thymine hydroxylase had been enriched more than 2000 times. Succinate has been indentified as a product in the partial reaction by capillary gas chromatography.

Although we have not identified a reaction product of the pyrimidines added there remains a possibility that they are oxidized in some way. The most likely interpretation of the results is that the 2-oxoglutarate decarboxylating activity obtained with inhibitors of thymine hydroxylase is an example of a partial reaction catalyzed by the native or a damaged form of the enzyme.

Experimental. The incubation system $(0.2 \mathrm{ml})$ contained purified thymine hydroxylase $(3.7 \mu \mathrm{g}$ with added thymine and $37 \mu \mathrm{g}$ with other pyrimidines). The concentrations of substrates and cofactors were: Pyrimidines $0.5 \mathrm{mM}, 2$ oxo[1-14 $\mathrm{C}_{1}$ ]glutarate $0.25 \mathrm{mM}$, ascorbate $5 \mathrm{mM}$, $\mathrm{FeSO}_{4} 1 \mathrm{mM}$, EDTA $0.05 \mathrm{mM}$, glycine $50 \mathrm{mM}$ in $50 \mathrm{mM}$ potassium phosphate buffer $\mathrm{pH} 7.5$. The incubations were carried out for $10 \mathrm{~min}$ at $37^{\circ} \mathrm{C}$ and stopped with an equal volume of $0.3 \mathrm{M}$ trichloroacetic acid. The ${ }^{14} \mathrm{CO}_{2}$ was trapped on a piece of filter paper soaked in $20 \mathrm{ul}$ of $1 \mathrm{M}$ Hyamine solution.

Acknowledgement. This work was supported by a grant from the Swedish Medical Research Council (13X-585).
1. Holme, E., Lindstedt, G., Lindstedt, S. and Tofft, M. J. Biol. Chem. 246 (1971) 3314.

2. Hamilton, G. A. Prog. Bioorg. Chem. 1 (1971) 83.

3. Holme, E. Proc. 10th Int. Congr. Biochem., Hamburg 1976, p. 348.

4. Counts, D., Cardinale, G. and Undenfriend, S. Proc. Natl. Acad. Sci. U.S.A. 75 (1978) 2145.

5. Rao, V. and Adams, E. J. Biol. Chem. 253 (1978) 6327.

6. Bankel, L., Lindstedt, G. and Lindstedt, S. Biochim. Biophys. Acta 481 (1977) 431.

Received June 5, 1979. 